\title{
Intestinal Obstruction in Autosomal Dominant Polycystic Kidney Disease
}

\author{
Kaheita Kakinoki, Yatsugi Noda, Masayoshi Takaeda, Masahiro Kubo, Keiichi Mrzuhashi, \\ Ichirou MiYAmoto, Tetsuya Nishida and Yasuhiro TAKEMORI
}

\begin{abstract}
A 42-year-old woman with autosomal dominant polycystic kidney disease (ADPKD) was admitted to our hospital on April 29, 1999, with complaints of abdominal pain. A diagnosis of intestinal obstruction was reached on the basis of clinical findings and $X$-ray evidence. A computed tomography scan of the abdomen showed massively enlarged kidneys, especially the right kidney, which seemed to compress the small intestine. The patient underwent percutaneous aspiration of the largest cysts on the surface of the right kidney. The symptoms, in this rare case of intestinal obstruction by an enlarged kidney in ADPKD, were alleviated the day after the aspiration procedure.

(Internal Medicine 41: 441-444, 2002)
\end{abstract}

Key words: ADPKD, percutaneous aspiration, small intestine, renal cyst, ileus

\section{Introduction}

Autosomal dominant polycystic kidney disease (ADPKD) is characterized by multiple bilateral cysts and kidney enlargement. However, the enlarged organs rarely directly interfere with the functioning of surrounding organ systems. We report here a case of ADPKD causing symptomatic intestinal obstruction.

For editorial comment, See p 415.

\section{Case Report}

A 42-year-old woman was admitted to our hospital on April 29,1999 , with complaints of abdominal pain and vomiting. Her father had died of renal failure. Four years previously the patient had been diagnosed with ADPKD. At that time, renal insufficiency was evidenced by a blood urea nitrogen level of 40 to $50 \mathrm{mg} / \mathrm{dl}$ and a serum creatinine level of 3 to $4 \mathrm{mg} / \mathrm{dl}$. However, she had not undergone any treatment because of an absence of symptoms until two days before admission, when she suddenly developed cramping abdominal pain and vomiting without any apparent cause. The pain had been continuing for two days, accompanied by nausea, constipation, accumulation of intestinal gas, and abdominal distention. As her condition did not improve, she was referred to our hospital.

An abdominal X-ray picture taken with the patient in the supine position revealed that the dilated small intestine contained an excessive amount of gas. A roentgenogram obtained with the patient in the upright position showed air-fluid levels in the small intestine (Fig. 1). Clinical findings plus the X-ray evidence led to a diagnosis of intestinal obstruction.

The patient's body temperature was $36.5^{\circ} \mathrm{C}$, blood pressure $158 / 94 \mathrm{mmHg}$, and pulse $68 / \mathrm{min}$. She was $152.0 \mathrm{~cm}$ tall and weighed $63.0 \mathrm{~kg}$. Physical examination showed the patient to be obese and in pain. There was no sign of conjunctivitis, the conjunctivas were normal and of a good color, and the sclera showed no signs of jaundice. The lungs were clear in response to percussion and auscultation. Heart sounds were normal without any audible murmur. The abdomen was markedly distended and diffusely tender, while bowel sounds were loud and metallic. No organs or masses could be identified by palpation. In spite of the abdominal distention, the extremities were relatively lean. Neurologic examination results were negative.

The hemoglobin level was $10.1 \mathrm{~g} / \mathrm{dl}$, and the white cell count $6,500 / \mathrm{mm}^{3}$. Renal function studies showed blood urea nitrogen at $108 \mathrm{mg} / \mathrm{dl}$, serum creatinine at $12.5 \mathrm{mg} / \mathrm{dl}$, and creatinine clearance at $6.0 \mathrm{ml} / \mathrm{min}$. The C-reactive protein level was normal. The urine was positive for protein $(++)$ and occult blood $(++)$; the sediment contained 6 to 10 red cells and 6 to 10 white cells per high-power field (Table 1). The patient was suffering from end-stage renal disease as a result of ADPKD.

A computed tomographic (CT) scan of the abdomen and pelvis showed that the bilateral kidneys were markedly enlarged due to the presence of enormous cysts occupying most of the abdomen and distorting other intraabdominal structures. The

From the Department of Internal Medicine, Toyama Rosai Hospital, Uozu

Received for publication September 14, 2001; Accepted for publication January 28, 2002

Reprint requests should be addressed to Dr. Yatsugi Noda, the Department of Internal Medicine, Toyama Prefectural Central Hospital, 2-2-78 Nishinagae, Toyama 930-8550 


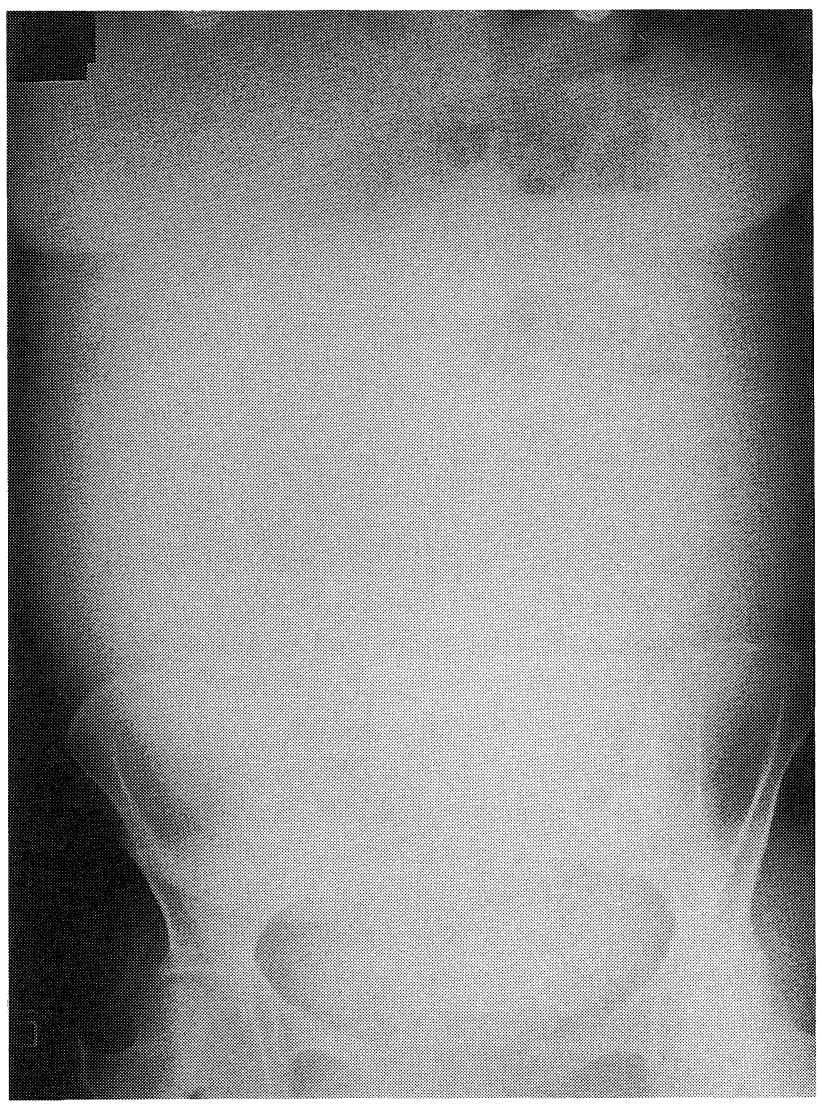

A

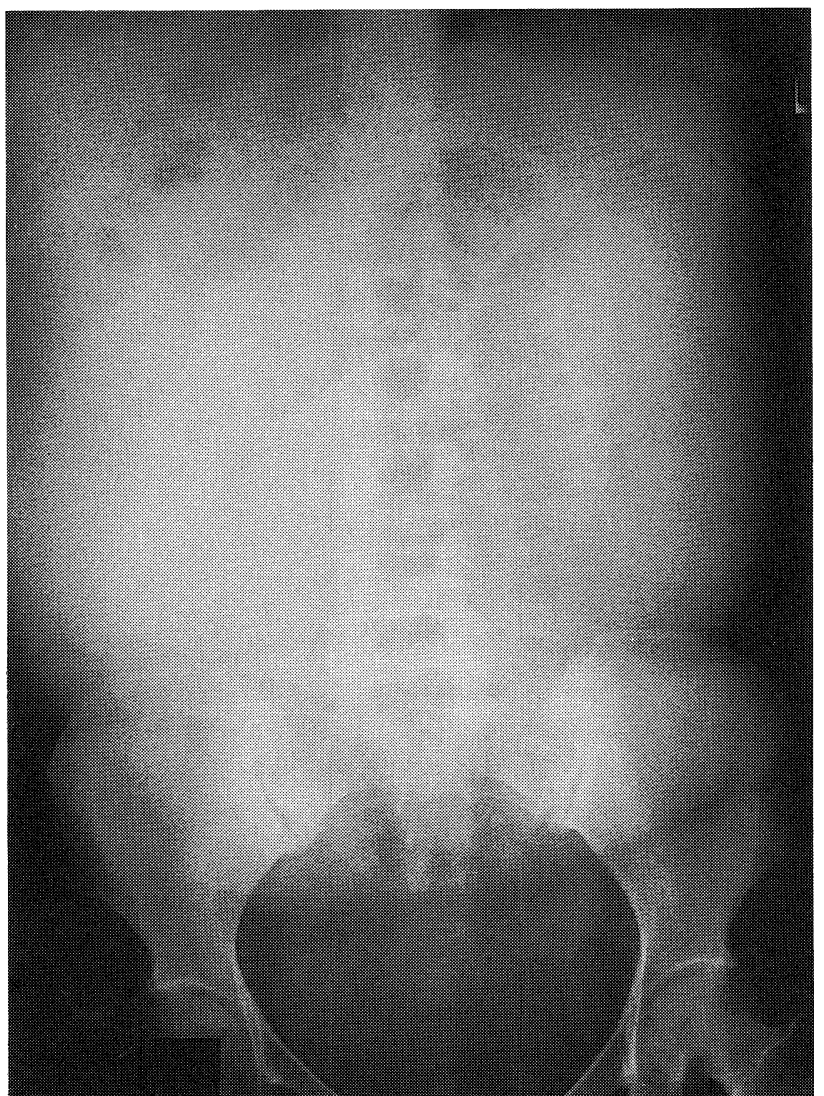

B

Figure 1. (A) An abdominal X-ray picture taken with the patient in the supine position shows an excessive amount of gas in the small intestine, but little or no colonic gas is seen. (B) A roentgenogram obtained with the patient in the upright position reveals air-fluid levels in the small intestine.

Table 1. Laboratory Findings on Admission

\begin{tabular}{|c|c|c|c|c|c|}
\hline Hematology & & AST & $17 \mathrm{IU} / l$ & $\underline{\text { Serological test }}$ & \\
\hline White blood cell & $6,500 / \mu 1$ & ALT & $13 \mathrm{IU} / l$ & C-reactive protein & $0.4 \mathrm{mg} / \mathrm{dl}$ \\
\hline Neutrophil & $72.8 \%$ & $\mathrm{LDH}$ & $604 \mathrm{IU} / l$ & & \\
\hline Eosinophil & $8.2 \%$ & ALP & $195 \mathrm{IU} / l$ & Tumor marker & \\
\hline Basophil & $0.6 \%$ & $\gamma$-GTP & $9 \mathrm{IU} / l$ & CEA & $4.0 \mathrm{ng} / \mathrm{ml}$ \\
\hline Lymphocyte & $13.0 \%$ & Total bilirubin & $0.06 \mathrm{mg} / \mathrm{dl}$ & & \\
\hline Monocyte & $5.4 \%$ & Total amylase & $101 \mathrm{U} / l$ & Urinalysis & \\
\hline Red blood cell & $334 \times 10^{4} / \mu 1$ & Blood urea nitrogen & $108 \mathrm{mg} / \mathrm{dl}$ & Protein & $100 \mathrm{mg} / \mathrm{dl}$ \\
\hline Hemoglobin & $10.1 \mathrm{~g} / \mathrm{dl}$ & Creatinine & $12.5 \mathrm{mg} / \mathrm{dl}$ & Sugar & $0.10 \mathrm{~g} / \mathrm{dl}$ \\
\hline Hematocrit & $30.9 \%$ & Uric acid & $9.0 \mathrm{mg} / \mathrm{dl}$ & Urobilinogen & $0.1 \mathrm{EU} / \mathrm{dl}$ \\
\hline \multirow[t]{2}{*}{ Platelet } & $30.8 \times 10^{4} / \mu 1$ & $\mathrm{Na}$ & $144 \mathrm{mEq} / \mathrm{l}$ & Occult blood & $(2+)$ \\
\hline & & $\mathrm{K}$ & $3.7 \mathrm{mEq} / \mathrm{l}$ & Sediment & \\
\hline Blood Chemistry & & $\mathrm{Cl}$ & $104 \mathrm{mEq} / \mathrm{l}$ & Red blood cell & $6-10 / \mathrm{HPF}$ \\
\hline Total protein & $6.8 \mathrm{~g} / \mathrm{dl}$ & $\mathrm{Ca}$ & $3.3 \mathrm{mEq} / \mathrm{l}$ & White blood cell & 6-10/HPF \\
\hline Albumin & $63.3 \%$ & $\mathrm{P}$ & $9.3 \mathrm{mg} / \mathrm{dl}$ & Hyaline cast & $(-)$ \\
\hline$\alpha 1$-globulin & $4.1 \%$ & $\mathrm{Fe}$ & $41 \mu \mathrm{g} / \mathrm{dl}$ & Granular cast & $(-)$ \\
\hline$\alpha 2$-globulin & $11.6 \%$ & & & Squamous epithelium & $(+)$ \\
\hline$\beta$-globulin & $8.6 \%$ & Creatinine clearance & $6.0 \mathrm{ml} / \mathrm{min}$ & & \\
\hline$\gamma$-globulin & $12.4 \%$ & & & & \\
\hline
\end{tabular}

AST: Aspartate aminotransferase, ALT: Alanine aminotransferase, LDH: Lactate dehydrogenase, ALP: Alkaline phosphatase, $\gamma$-GTP: gamma-glutamyl transpeptidase, CEA: carcinoembryonic antigen. 


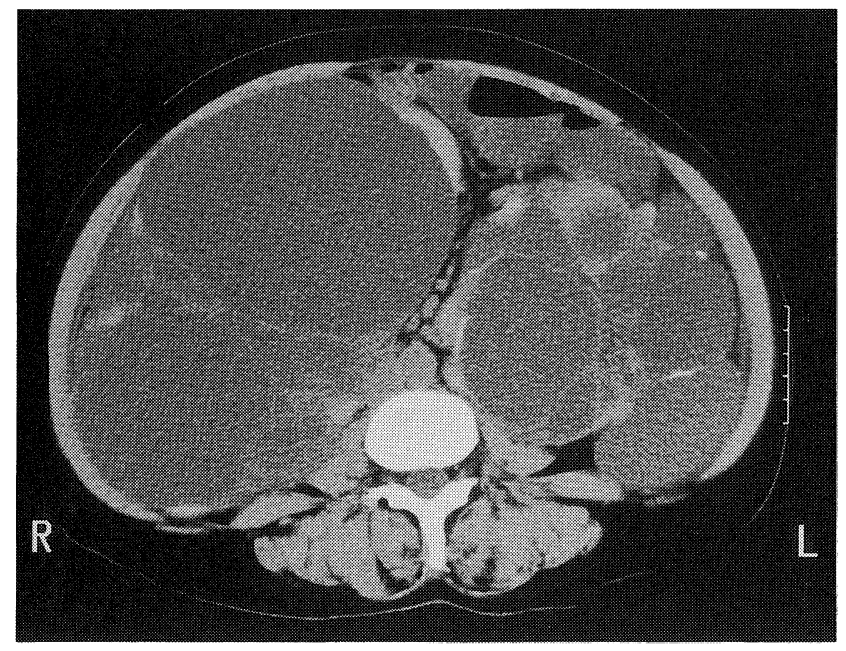

A

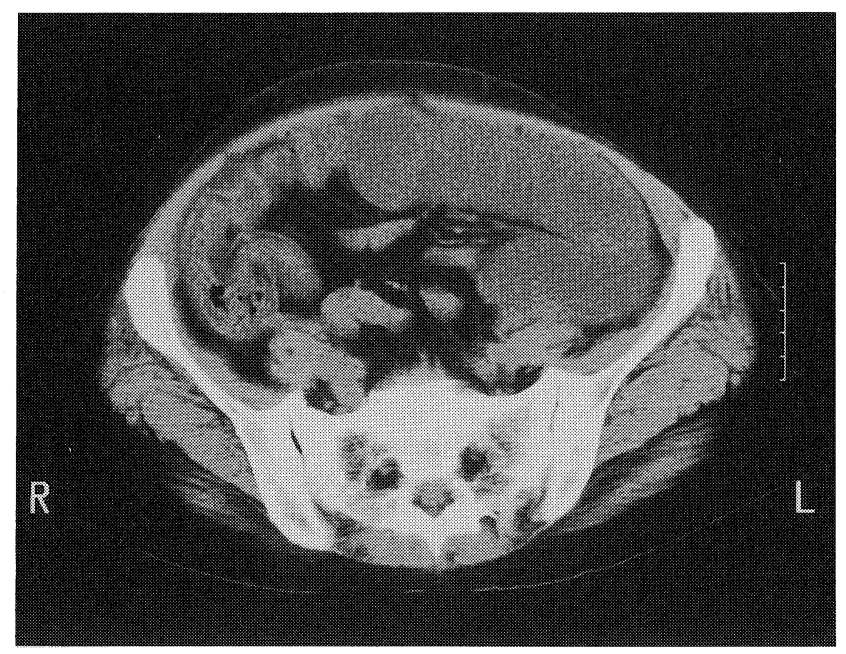

B

Figure 2. A computed tomographic scan of the abdomen and pelvis shows massively enlarged polycystic kidneys (A) and dilatation of the small intestine filled with fluid $(B)$.

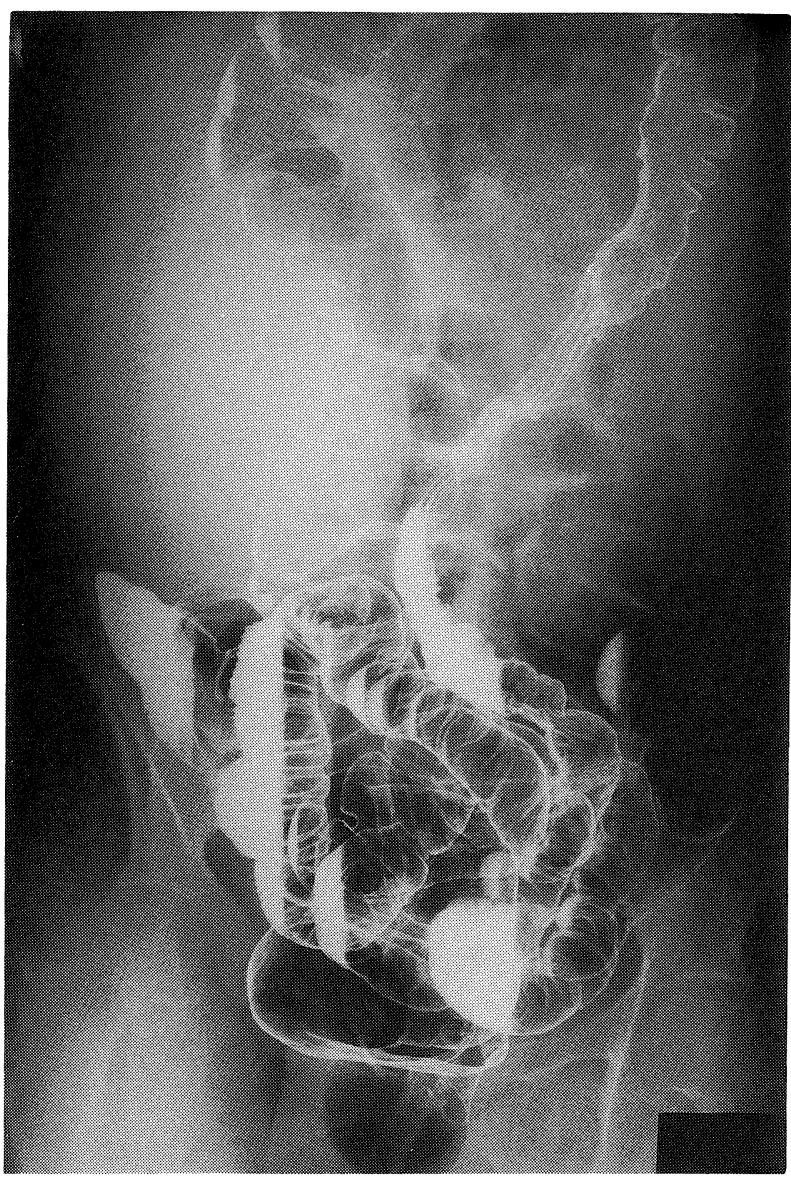

Figure 3. Barium enema shows medial deviation of the ascending and descending colons due to compression by the enlarged kidneys. right kidney measured $25.0 \times 20.5 \times 12.0 \mathrm{~cm}$ and the left kidney $23.0 \times 15.5 \times 11.0 \mathrm{~cm}$, so that enlargement of the right kidney was especially pronounced.

The small intestine was markedly dilated and filled with fluid, but without distention of the colon (Fig. 2). The exact location of the obstruction was not clear, but it seemed most likely that the large right kidney was compressing the small intestine.

On admission, conservative treatment was soon started with fasting and replacement of fluid. However, the symptoms progressively worsened and the abdomen became spastic during the conservative management. On the second day of hospitalization, percutaneous needle aspiration of the largest cysts on the surface of the right kidney was performed to alleviate the symptoms of obstruction. Under ultrasound guidance, an 18gauge needle was introduced into the cysts through the right flank and a total of $1,130 \mathrm{ml}$ of turbid yellow fluid was evacuated. The cells and culture of the fluid were normal. Abdominal pain and fullness were alleviated soon after cyst aspiration, and on the following day, the symptoms caused by intestinal obstruction had disappeared. An abdominal X-ray showed that the amount of gas in the small intestine had decreased, and a barium enema administered after the symptoms had vanished revealed an abnormal intestinal shape with medial deviation of the ascending and descending colons due to compression of the enlarged kidneys (Fig. 3). Finally, colonoscopic examination showed no obstruction of the colon. Despite relief of intestinal obstruction, however, the renal function did not improve and the serum creatinine level was still $11.4 \mathrm{mg} / \mathrm{dl}$ on the 15th hospital day. For this reason, an AV fistula was created for hemodialysis during the patient's hospital stay. The patient was discharged on the 38th hospital day and since then hemodialysis has been performed at our clinic. There has been 
KAKINOKI et al

Table 2. Reported Cases of Intestinal Obstruction in Polycystic Kidney Disease

\begin{tabular}{ccccccc}
\hline Case & Age & Sex & Author & Year & Location & Treatment \\
\hline 1. & 53 & F & Moadel E et al & 1975 & Duodenum & Not done \\
2. & Neonate & F & Garland N et al & 1977 & Duodenum & Nephrectomy \\
3. & 64 & F & Bednarz W et al & 1992 & Small intestine & Nephrectomy \\
4. & 35 & M & Fried LF et al & 1998 & Duodenum & Nephrectomy \\
5. & 42 & F & Present case & 1999 & Small intestine & Percutaneous needle aspiration \\
\hline
\end{tabular}

no recurrence 24 months after discharge.

\section{Discussion}

ADPKD is one of the most common hereditary disorders, characterized by multiple bilateral cysts and kidney enlargement. By age 50 the kidneys can be enormous, reaching up to $40 \mathrm{~cm}$ in length and $8 \mathrm{~kg}$ in weight (1). In spite of the large size of the kidneys, obstruction of surrounding organs has rarely been reported (2). Diverticulosis of the colon is generally recognized as a common extrarenal manifestation of ADPKD (3). However, little is known about intestinal obstruction as a result of ADPKD.

As far as we could determine, only five cases, including ours, of polycystic kidney disease complicated by intestinal obstruction have been reported, three of obstruction of the duodenum and two of the small intestine. All cases underwent nephrectomy $(2,4-7)$ except one who died of renal failure (6) (Table 2). In our case, conservative medical treatment for intestinal obstruction was started. Because the abdominal CT indicated that the right kidney was compressing the small intestine, the patient was treated with ultrasound guided percutaneous aspiration of cyst fluid. Cyst aspiration under ultrasound guidance is generally performed for ADPKD which is accompanied by pain and is unresponsive to medical management $(8$, 9). However, such cysts typically recur with pain within 3 to 6 months because of the relatively rapid reaccumulation of fluid (10). In the present case, however, there was no recurrence of the intestinal obstruction even though an abdominal CT scan performed 3 months after the cyst aspiration revealed reaccumulation of fluid in the cyst and enlargement of the kidney. Percutaneous needle aspiration of cyst fluid thus appears to be an effective treatment for the acute phase of intestinal obstruction in ADPKD.

If the present patient shows recurrence of intestinal obstruction, percutaneous instillation of iophendylate or alcohol following aspiration, cyst reduction surgery, or nephrectomy will need to be considered (10). Recently Ubara et al reported a patient with ADPKD who underwent successful transcatheter arterial embolization (TAE) of the renal arteries, which led them to suggest that TAE was effective for shrinking enlarged kidneys without significant complications (11). TAE thus also seems to be an effective technique for preventing the relapse of intestinal obstruction in ADPKD.

\section{Conclusion}

We described a rare case of intestinal obstruction by an enlarged kidney with giant cysts associated with ADPKD. Aspiration of cyst fluid under ultrasound guidance seems to be valuable to try as an emergency procedure for acute intestinal obstruction in ADPKD.

\section{References}

1) Gabow PA, Bennett WM. Renal manifestations: Complication management and long-term outcome of autosomal dominant polycystic kidney disease. Semin Nephrol 11: 643-652, 1991.

2) Fried LF, Palevsky PM, Johnston JR. Duodenal obstruction in polycystic kidney disease. Case report and review of the literature. Am J Nephrol 18: 318-320, 1998.

3) Kaehny WD, Everson GT. Extrarenal manifestations of autosomal dominant polycystic kidney disease. Semin Nephrol 11: 661-670, 1991.

4) Gabow PA. Autosomal dominant polycystic kidney disease. N Engl J Med 329: 332-342, 1993.

5) Bednarz W, Dawiskiba J, Krawczyk Z. Giant cystic kidney as the cause of mechanical ileus. Wiad Lek 45: 920-924, 1992 (in Polish, Abstract in English).

6) Moadel E, Bryk D. Idiopathic intestinal pseudo-obstruction. Am J Gastroenterol 63: 162-165, 1975.

7) Porterfield GN, Campbell DP. Duodenal obstruction in a newborn secondary to a multicystic kidney. J Pediatr Surg 12: 767-769, 1997.

8) Bennett WM, Elzinga LW. Clinical management of autosomal dominant polycystic kidney disease. Kidney Int 44 (Suppl. 42): S74-S79, 1993.

9) Higashihara E, Nutahara K, Minowada S, et al. Percutaneous reduction of cyst volume of polycystic kidney disease: effects on renal function. $\mathrm{J}$ Urology 147: 1482-1484, 1992.

10) Elzinga LW, Barry JM, Bennett WM. Surgical management of painful polycystic kidneys. Am J Kidney Dis 22: 532-537, 1993.

11) Ubara $Y$, Katori H, Tagami T, et al. Transcatheter renal arterial embolization therapy on a patient with polycystic kidney disease on hemodialysis. Am J Kidney Dis 34: 926-931, 1999. 